\title{
PENETAPAN KADAR FLAVONOID TOTAL DARI EKSTRAK ETANOLIK DAUN BENALU MANGGA (Dendrophthoe pentandra L. Miq)
}

\author{
${ }^{1}$ Rizki Yulianti R, Amaliah Dahlia, ${ }^{2}$ Aktsar Roskiana Ahmad \\ ${ }^{1}$ Laboratorium Farmakognosi-Fitokimia \\ Fakultas Farmasi \\ Universitas Muslim Indonesia \\ Email: ${ }^{1}$ rizki_ratulangi@yahoo.com,dahliaamalia@yahoo.co.id, \\ 2aktsar.roskiana@umi.ac.id,
}

\begin{abstract}
Mistletoes (Dendrophthoe pentandra L. Miq) is one of the medicine plant which used traditionally to remedy the various of disease. Empirically, communities used mistletoes leaves as cough, tonsillitis, measles, cancer, diuretic, and pain relievers. This research is aimed to determine total flavonoid content in extract of mistletoes leaves (Dendrophthoe pentandra L. Miq). Extraction has done with Thin Layer Cromathography (KLT) method to determine active content which in sample. Analysis of chemistry content in ethanolic extract of mistletoes leaves show are flavonoid content. Content of total flavonoid with Chang et al., 2002 method using UV-Vis spectrophotometry at a wavelength of $440 \mathrm{~nm}$. From this research result $39.713 \mathrm{~g}$ ethanolic extract with percent of extract rendamen is $6.109 \%$ from $650 \mathrm{~g}$ dry powder of mistletoes leaves. The results of total flavonoid of ethanolic extract of mistletoes leaves is $2.48 \%$ calculated as quercetin.
\end{abstract}

Keywords : Mistletoes leaves, Dendrophthoe pentandra L. Miq, Total Flavonoid, Quercetin

\section{PENDAHULUAN}

Latar Belakang

Penggunaan obat tradisional telah lama digunakan sejak zaman dahulu hingga sekarang, baik di negara maju maupun yang sedang berkembang. Menurut World Healthy Organization (WHO), hampir $80 \%$ umat manusia, menggantungkan dirinya pada tumbuh-tumbuhan sebagai bahan obat dalam memelihara kesehatannya (Choirul, 2003).

Pemakaian bahan herbal alami untuk menangani penyakit dipercaya dapat membantu memberikan efek kesembuhan dengan memanfaatkan metabolit sekunder yang dihasilkan seperti, flavonoid.

Flavonoid merupakan senyawa polifenol yang mengandung 15 atom karbon dalam inti dasarnya yang tersusun dalam konfigurasi C6-C3-C6, yaitu dua cincin aromatik yang dihubungkan oleh satuan tiga karbon yang dapat atau tak dapat membentuk cincin ketiga (Markham, 1988).

Menurut penelitian Artanti et al., (2006) menyatakan bahwa sejumlah tanaman obat yang mengandung flavonoid telah di laporkan memiliki aktivitas antioksidan, antibakteri, antivirus, antiradang, antialergi dan antikanker, di antaranya benalu mangga. Benalu merupakan salah satu tumbuhan yang cukup menjanjikan dan masih membutuhkan eksplorasi lebih lanjut. Selain dapat digunakan dalam sediaan tradisional (jamu), benalu juga berpeluang dijadikan sebagai fitofarmaka (Artanti et al., 2006).

Benalu yang merupakan tumbuhan parasit, ternyata berpotensi sebagai antikanker. Salah satu senyawa yang terkandung dalam benalu dan beraktivitas antikanker adalah flavonoid (Ikawati, et al., 2008).

Pada penelitian sebelumnya, ekstrak etanolik daun benalu mangga (Dendrophthoe pentandra L. Miq) memiliki aktivitas antiradikal bebas (Fajriah, et al., 2007).

Berdasarkan uraian tersebut, maka perlu dilakukan penelitian yang lebih intensif mengenai pengujian kadar flavonoid total dari ekstrak etanolik daun benalu mangga, sehingga potensi tumbuhan ini sebagai bahan baku obat untuk pencegahan maupun pengobatan berbagai penyakit dapat lebih dikembangkan dengan maksimal. 


\section{METODOLOGI PENELITIAN}

\section{Pengambilan Sampel}

Sampel daun benalu mangga (Dendrophthoe pentandra L. Miq) diambil dari inangnya, dikumpulkan kemudian dipisahkan daunnya. Setelah itu dilakukan sortasi basah untuk menghilangkan tanah dan pengotor lainnya yang masih menempel pada sampel.

\section{Pengolahan Sampel}

Daun benalu mangga (Dendrophthoe pentandra L. Miq) yang telah diambil dilakukan pengubahan bentuk dengan cara dipotong-potong kecil, selanjutnya dikeringkan dengan cara dianginanginkan selama beberapa hari pada udara terbuka dengan tidak terkena sinar matahari langsung. Setelah kering sampel ditimbang dan dicatat berat keringnya kemudian diserbukkan setelah itu ditimbang kembali berat serbuk, berat sampel serbuk yang diperoleh yaitu 650 gram.

\section{Ekstraksi Sampel}

Sebanyak 650 gram serbuk daun benalu mangga (Dendrophthoe pentandra L. Miq) dimasukkan ke dalam wadah maserasi, ditambahkan pelarut etanol $96 \%$ hingga serbuk simplisia terendam dengan volume etanol 2 liter, dibiarkan selama 3-4 hari. Setelah proses ekstraksi selesai diperoleh ekstrak kental sebanyak $800 \mathrm{~mL}$ untuk hasil saringan pertama kemudian hasil remaserasi yaitu $600 \mathrm{~mL}$. Ekstrak kental yang telah dikumpulkan lalu diuapkan dengan menggunakan alat water bath dan hair drayer hingga diperoleh ekstrak etanolik kering, hasil ekstrak etanolik kering yang diperoleh sebanyak 39,713 gram.

\section{Uji Kualitatif Flavonoid}

Untuk uji kualitatif flavonoid, dilakukan analisis KLT. Ekstrak etanolik daun benalu mangga dilarutkan dengan etanol 96\% kemudian ditotolkan pada lempeng KLT. Lempeng dimasukkan dalam chamber yang berisi eluen n-heksan : etil asetat $(1: 9)$. Bercak diamati dibawah sinar $\mathrm{UV}_{366} \mathrm{~nm}$. Kemudian disemprot dengan reagen atau pereaksi spesifik. Pereaksi yang sering digunakan untuk identifikasi flavonoid sebagai pereaksi semprot dalam KLT adalah $\mathrm{AlCl}_{3}$ dan sitroborat yang akan memberikan warna kuning (Mabry et al., 1970).

\section{Uji Kuantitatif Flavonoid}

a. Pembuatan larutan standar kuersetin

Ditimbang sebanyak $25 \mathrm{mg}$ baku standar kuersetin dan dilarutkan dalam $25 \mathrm{~mL}$ etanol $96 \%$. Larutan stok dipipet sebayak 1 $\mathrm{mL}$ dan dicukupkan volumenya sampai 10 $\mathrm{mL}$ dengan etanol 96\% untuk $1000 \mathrm{ppm}$. Dipipet kembali $5 \mathrm{~mL}$ kemudian dicukupkan volumenya sampai $50 \mathrm{~mL}$ dengan etanol 96\%. Dari larutan standar kuersetin 100 ppm, kemudian dibuat beberapa konsentrasi yaitu 2 ppm, 4 ppm, 6 ppm, 8 ppm, dan 10 ppm. Dari masing-masing konsentrasi larutan standar kuersetin ditambahkan $3 \mathrm{~mL}$ etanol 96\%, 0,2 $\mathrm{mL} \mathrm{AlCl}_{3}, 0,2 \mathrm{~mL}$ kalium asetat $1 \mathrm{M}$, dan 5,6 $\mathrm{mL}$ aquabidestillata. Setelah itu diinkubasi selama 30 menit pada suhu kamar dan diukur absorbansinya pada spektrofotometer $U V$ Visible dengan panjang gelombang $440 \mathrm{~nm}$.

\section{b. Pembuatan larutan sampel}

Kandungan flavonoid total merujuk pada prosedur Chang et al., (2002) dengan beberapa konsentrasi menggunakan kuersetin sebagai standar. Ditimbang ekstrak etanolik daun benalu mangga sebanyak $25 \mathrm{mg}$ dan dilarutkan dalam $25 \mathrm{~mL}$ etanol $96 \%$. Dari larutan stok dipipet sebayak $1 \mathrm{~mL}$ dan dicukupkan volumenya sampai $10 \mathrm{~mL}$ dengan etanol 96\%. Kemudian dipipet $1 \mathrm{~mL}$ dan ditambahkan $3 \mathrm{~mL}$ etanol $96 \%, 0,2 \mathrm{~mL}$ $\mathrm{AlCl}_{3}, 0,2 \mathrm{~mL}$ kalium asetat $1 \mathrm{M}$, dan 5,6 mL aquabidestillata. Setelah itu diinkubasi selama 30 menit pada suhu kamar dan diukur absorbansinya pada spektrofotometer UVVisible dengan panjang gelombang $440 \mathrm{~nm}$. Larutan sampel dibuat dalam tiga kali replikasi.

\section{HASIL DAN PEMBAHASAN}

Sampel daunbenalu manga 650 gram diekstraksi secara maserasi yaitu menggunakan pelarut etanol sebanyak $2 \mathrm{~L}$, menghasilkan ekstrak kental etanol yaitu 39,713 gram dengan persen rendamen sebesar $6,109 \%$.

Identifikasi golongan senyawa kimia menggunakan $\mathrm{KLT}_{254}$ dengan fase gerak nheksan:etil asetat (1:9). Kemudian disemprot pereaksi spesifik sitroborat dan $\mathrm{AlCl}_{3}$, tampak 2 bercak berpendar kuning kehijauan dibawah $\mathrm{UV}_{366} \mathrm{~nm}$ dengan nilai $\mathrm{Rf}_{1}$ 0,9 dan $\mathrm{Rf}_{2}$ 0,6. Hasil skrining fitokimia pada ekstrak etanolik daun benalu mangga, menunjukkan 
bahwa sampel positif mengandung senyawa flavonoid.

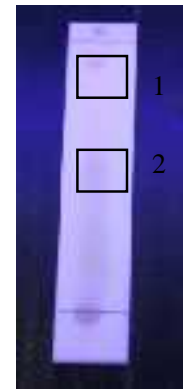

(a)

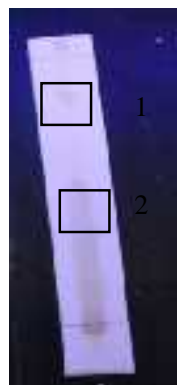

(b) pembanding dalam analisis kuantitatif pada pengukuran kandungan senyawa flavonoid kuersetin terhadap ekstrak etanolik daun benalu mangga.

Tabel 2. Hasil pengukuran absorbansi standar kuersetin

\begin{tabular}{cc}
\hline $\begin{array}{c}\text { Konsentrasi } \\
(\mu \mathrm{g} / \mathrm{mL})\end{array}$ & Absorbansi $(\lambda) 440 \mathrm{~nm}$ \\
\hline 2,0 & 0,067 \\
4,0 & 0,078 \\
6,0 & 0,092 \\
8,0 & 0,106 \\
10,0 & 0,118 \\
\hline
\end{tabular}

Gambar 1. Profil KLT ekstrak etanolik daun benalu mangga

Keterangan :

Fase diam : Silika gel $60 \mathrm{~F}_{254}$

Fase gerak : n-heksan-etil asetat (1:9)

(a) Deteksi $\mathrm{UV}_{366}$ dan pereaksi semprot $\mathrm{AlCl}_{3}$

(b) Deteksi $\mathrm{UV}_{366}$ dan pereaksi semprot Sitroborat

Tabel 1. Hasil uji kualitatif senyawa flavonoid ekstrak etanolik daun benalu mangga

\begin{tabular}{|c|c|c|}
\hline Sampel & $\begin{array}{c}\mathrm{AlCl}_{3} \\
\mathrm{UV}_{366} \mathrm{~nm}\end{array}$ & $\begin{array}{l}\text { Sitroborat } \\
\mathrm{UV}_{366} \mathrm{~nm}\end{array}$ \\
\hline $\begin{array}{c}\text { Ekstrak } \\
\text { Etanolik } \\
\text { Daun } \\
\text { Benalu } \\
\text { Mangga }\end{array}$ & $\begin{array}{c}\text { Warna } \\
\text { Kuning }\end{array}$ & $\begin{array}{l}\text { Warna } \\
\text { Kuning }\end{array}$ \\
\hline
\end{tabular}

Penentuan kadar flavonoid dengan menggunakan metode Chang pada tahun 2002 dan sebagai pembanding digunakan baku standar kuersetin. Kemudian dilakukan optimasi panjang gelombang untuk menentukan $\lambda$ maksimum yang akan digunakan dalam pengukuran pada spektrofotometri UV-Vis. Hasil pengukuran diperoleh panjang gelombang maksimum yaitu $440 \mathrm{~nm}$.

Hasil pengukuran absorbansi larutan standar kuersetin pada beberapa konsentrasi (ppm) yaitu 2, 4, 6, 8 dan 10 diperoleh hubungan yang linear antara absorbansi dengan konsentrasi yaitu sebesar 0,9983. Dari hasil perhitungan, diperoleh nilai intersep sebesar 0,0065 dan nilai slope sebesar 0,0532 sehingga persamaan kurva baku adalah $\mathrm{y}=0,0065 \mathrm{x}+0,0532$. Persamaan tersebut digunakan sebagai

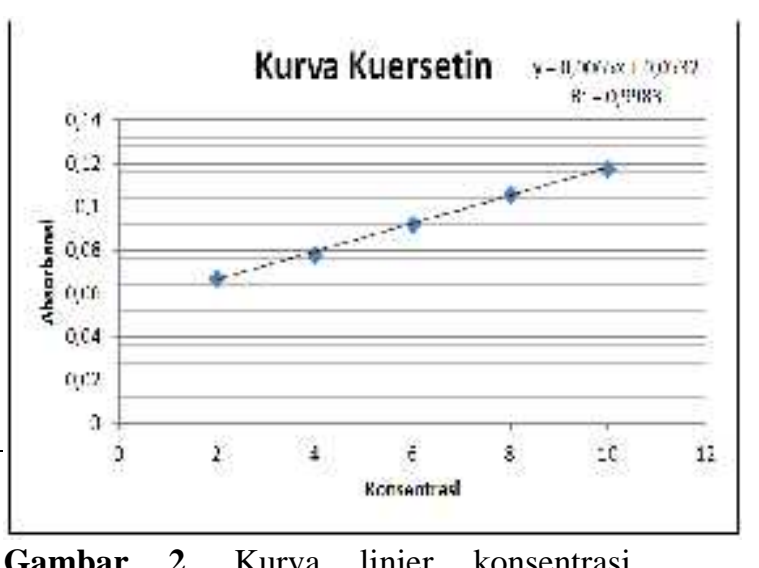
Kurva linier konse
kuersetin pada $\lambda 440 \mathrm{~nm}$

Tabel 3. Hasil pengukuran absorbansi ekstrak etanolik daun benalu manga

\begin{tabular}{cccc}
\hline Sampel & \multicolumn{3}{c}{ Absorbansi } \\
\cline { 2 - 4 } & Replikasi I & $\begin{array}{c}\text { Replikasi } \\
\text { II }\end{array}$ & $\begin{array}{c}\text { Replikasi } \\
\text { III }\end{array}$ \\
Ekstrak & & & \\
Etanolik & 0,0903 & 0,0946 & 0,0967 \\
$\begin{array}{c}\text { Daun Benalu } \\
\text { Mangga }\end{array}$ & & & \\
\hline
\end{tabular}

Tabel 4. Hasil pengukuran kadar flavonoid total ekstrak etanolik daun benalu manga

\begin{tabular}{cccc}
\hline Replikasi & $\begin{array}{c}\text { Kandungan } \\
\text { flavonoid } \\
\text { awal } \\
(\mathrm{mg} / \mathrm{mL})\end{array}$ & $\begin{array}{c}\text { Flavonoid } \\
\text { total }(\mathrm{g} . \\
\mathrm{QE} / \mathrm{g} . \\
\text { eks })\end{array}$ & $\begin{array}{c}\text { \%Kadar } \\
\text { flavonoid }\end{array}$ \\
\hline 1 & 0,0057 & 0,0228 & \\
2 & 0,0063 & 0,0252 & $2,48 \%$ \\
3 & 0,0066 & 0,0264 & \\
\hline
\end{tabular}


Flavonoid total pada ekstrak etanolik daun benalu mangga diperoleh dengan cara memasukkan nilai absorbansi pada kurva standar kuersetin sehingga hasil dari besar flavonoid total ekstrak etanolik daun benalu mangga yaitu sebesar $2,48 \%$.

Pada penelitian yang dilakukan Fajriah tahun 2007 menunjukkan adanya korelasi linear antara flavonoid dengan aktivitas antioksidan. Sehingga tingginya kadar flavonoid ekstrak etanolik daun benalu mangga, sejalan dengan aktivitas antioksidan yang diperoleh nilai $\mathrm{IC}_{50}$ yaitu $25,40 \mu \mathrm{g} / \mathrm{mL}$.

\section{KESIMPULAN}

Berdasarkan hasil penelitian yang telah dilakukan, maka dapat disimpulkan bahwa daun benalu mangga (Dendrophthoe pentandra L. Miq) mengandung senyawa flavonoid total sebesar $2,48 \%$ dihitung terhadap atau sebagai kuersetin.

\section{DAFTAR PUSTAKA}

1. Artanti, N. M., Hanafi, M. Y. 2006. Isolation and identification of active antioxsidant compound from star fruit mistletoe Dendrophthoe pentandra (Ethanol extract, Journal of aplied sciences 6(8) 1659-1663) (online), diakses 10 september 2013.

2. Chang, C. C., Yang, M. H., Wen, H. M., Chern, J. C., 2002. Estimation of total flavonoid content in propolis by two complementary colorimetric methods. $J$ Food Drug Ana. 10:178-182.

3. Choirul. 2003. Berita Biologi : Jurnal Ilmiah Nasional. Pusat Penelitian Biologi, Vol. 6 No. 4.

4. Departemen Kesehatan Republik Indonesia. Direktorat Pengawasan Obat Tradisional. 2000. Parameter standar umum ekstrak tumbuhan obat. Jakarta: Depkes RI.
5. Ditjen POM. 1979. Farmakope indonesia. (Edisi III). Jakarta: Depkes RI.

6. Ditjen POM. 1986. Sediaan galenik. Jakarta: Depkes RI.

7. Ditjen POM. 2000. Parameter standar umum ekstrak tumbuhan obat. Jakarta: Depkes RI.

8. Fajriah, A. D., Andini, S., Artanti, N. 2007. Isolasi senyawa antioksidan dari ekstrak etil asetat daun benalu (Dendrophthoe pentandra) yang tumbuh pada inang lobi-lobi. Pusat Penelitian Kimia - Lembaga Ilmu Pengetahuan Indonesia Kawasan Pusitek. Serpong.

9. Harborne, J.B. 1987. Metode fitokimia. (Edisi 2). Penerjemah: K. Padmaewinata dan I. Soediro. Bandung: Penerbit ITB.

10. Ikawati, M., Wibowo, A.E., Octa, N.S. Adelina, R., 2008. Pemanfaatan benalu sebagai agen antikanker. Yogyakarta: Universitas Gadjah Mada.

11. Khopkar. 1990. Konsep dasar kimia analitik. Jakarta: UI Press.

12. Mabry,T.J., Markham, K.R. \& Thomas, M.B. 1970. The systematic identification of flavonoid. Berlin: Spinger-Verlag.

13. Markham, K.H., 1988. Cara Mengidentifikasi Flavonoid. (Edisi 2). Penerjemah: K. Padmaewinata dan I. Soediro. Bandung: Penerbit ITB. 